Arq. Bras. Med. Vet. Zootec., v.66, n.2, p.445-449, 2014

\title{
Echobiometrics kidney and renal artery triplex doppler of canine fetuses
}

\author{
[Ecobiometria renal e Doppler Triplex da artéria renal de fetos caninos]
}

M.A.R. Feliciano, D.J. Cardilli, A.C. Nepomuceno, R.M. Crivalero, M.A.M. Silva, L.N. Coutinho, M.E.F. Oliveira, W.R.R. Vicente

Faculdade de Ciências Agrárias e Veterinárias - Unesp-Jaboticabal - Jaboticabal, SP

\begin{abstract}
The aim of this study was to assess the sogographic parameters and biometry of canine fetal kidneys using the B mode, and to determinate the vascular index of the fetal renal arteries using the Doppler Triplex. Twenty four Shi-tzu and Pug, weighting between 4 and $10 \mathrm{~kg}$, aging between 4 and 6 years old were evaluated. The B mode, the fetal renal echobiometry and regularity of the renal surface, echotexture and cortex:medular ratio were evaluated during the 5th, 6th, 7th and 8th weeks of pregnancy. At the same time point of the B mode evaluation, the Doppler Triplex was carried out to assess the sistolic peak velocity (SPV), end diastolic velocity (EDV), vascular resistive (RI) and pulsatility index (PI). B mode revealed no fetal renal abnormalities and echobiometry showed important measurements during fetal development $(\mathrm{P}<0.0001)$. The values of the fetal renal arteries index (PSV and EDV) increased during the course of the pregancy $(\mathrm{P}<0.05)$ and remained constant for PI and RI $(\mathrm{P}>0.05)$. B mode and Doppler Triplex were important tools for the assessment of fetal renal development, using echobiometry and renal arterial index in canie fetuses.
\end{abstract}

Keywords: canine, kidney, fetuses, B-mode ultrasound, vascular index

\section{RESUMO}

O objetivo deste estudo foi avaliar, por meio da ultrassonografia convencional modo $B$, as características sonográficas e a biometria dos rins de fetos caninos, bem como determinar os índices vasculares da artéria renal dos conceptos ao Doppler Triplex. Foram utilizadas 24 fêmeas Shi-tzu e Pugs pesando de quatro a $10 \mathrm{~kg}$ e com idade entre quatro e seis anos. Ao modo B, a ecobiometria renal fetal, a regularidade da superfície renal, a ecotextura e a relação córtico-medular foram avaliadas durante a quinta, sexta, sétima e oitava semanas gestacionais. Ao Doppler Triplex, durante o mesmo período em que se realizou o exame convencional, foram determinados o pico de velocidade sistólica (PVS), a velocidade diastólica final (EDV) e o índice de resistência vascular (RI) e de pulsatividade (PI). Ao modo $B$, não foram detectadas alterações em rins fetais, e à ecobiometria renal dos fetos, foi possível determinar medidas renais importantes, verificando-se aumento das biometrias no decorrer do desenvolvimento fetal $(P<0,0001)$. Ao Doppler Triplex, determinaram-se os índices vasculares da artéria renal fetal, sendo que os valores para PSV e EDV aumentaram no decorrer das semanas gestacionais $(P<0,05)$ e permaneceram constantes para PI e RI $(P>0,05)$. Concluiu-se que o modo B e o Doppler Triplex são ferramentas importantes para a avaliação do desenvolvimento renal fetal, com a utilização da ecobiometria renal e avaliação dos indices vasculares da artéria renal de fetos caninos.

Palavras-chave: cão, rins, fetos, ultrassom convencional modo B, índices vasculares

\section{INTRODUCTION}

The scope of the current studies in the veterinary setting have been to discover new methods of early detection of renal disease, such as biometry and dopppler flowmetry (Melo et al., 2006).

Recebido em 30 de agosto de 2012

Aceito em 1 de outubro de 2013

E-mail: marcusfeliciano@yahoo.com.br
The renal biometry allows for the detection of uni or bilateral misdiagnosed abnormalities of the kidneys. The chronic interstitial nefritis and the stenosis of the renal artery, for example, usually result in decreased renal morphologic parameters, while acute pielonefritis, policystic disease and hydronefrosis can lead to renal enlargement (Sampaio et al., 2002). 
Studies based on Doppler blood flow allow for the detection of organic hemodinamic changes, which contribute for precise diagnosis and better knowledge of the physiopathology. The alteration of the renal perfusion may be the first sign of abnormal renal function. Decreased renal perfusion may be assimptomatic in the early stages and can trigger glomerular, tubular and vascular disorders, which can lead to irreversible diseases (Melo et al., 2006).

Animal models have been used to show the versatility of Doppler techiniques on the assessment of several renal diseases. Doppler was essential for the early-stage diagnosis of dogs bearing nefritis, acute renal injury and glomerular disease (Rivers et al., 1997). In canine fetuses, pulse Doppler revealed a decrease in the percentage of renal vascular index in complicated pregnancy cases.

In order to determine reference values for echobiometry kidney and renal vascular indices in fetuses, as methods for early diagnosis of congenital renal diseases in dogs, the aim of the present study was to evaluate by B mode and Triplex Doppler sonographic features, the echobiometry of the canines' fetal kidneys and parameters of renal artery blood flow of the conceptus.

\section{MATERIAL AND METHODS}

Twenty four multiparous Shi-tzu $(\mathrm{n}=12)$ and Pug $(n=12)$ bitches from the same kennel, weighting 4-10kg, aging 4-6 years old, were selected for the current study. The animals were previously submitted to physical and obstetric examinations (inspection of the external genitalia, abdominal palpation and ultrasonography of the reproductive system), entering in the study only those which were healthy and considered suitable for reproduction.

The current trial was conduced following approval by the Animal Welfare and Ethics Committee of the School of Agrarian and Veterinary Sciences of the São Paulo State University (FCAV/UNESP - Jaboticabal).
The kennel owner was trained to detect the first signs of proestrus, in order to determinate the dogs' optimal mating period. The confirmation of the optimal fertility period was carried out by observing the signs of estrus (i.e., female's acceptance of coupling) and using vaginal cytology. The female in estrus and the male were put together for three days or artificial insemination was performed. In case natural mating was preferred, the bitches's acceptance to the courting male was inspected and assured.

Pregnancy diagnosis was carried out after two weeks of the mating or insemination, according to methodology employed in other trials (Feliciano et al., 2007). Ultrasound was performed with a $12.0 \mathrm{MHz}$ linear transducer using MyLab VET 30 ultrasound equipment (ESAOTE). The US examinations were carried out by a single examinator.

The B mode US and determination of the longitudinal aspect of the fetal renal echobiometry (i.e., length, width and area) and renal volume was performed on the 5 th, 6 th, 7 th and 8th week of pregnancy. Regularity of fetal renal surface, echotexture and cortical-medular ratio were also evaluated.

Triplex Doppler was used to assess the maximum velocity (peak systolic velocity), minimum velocity, resistance index and pulsatility index of fetal renal vascularization (Fig. 1)

Pulse Doppler was employed for the determination of renal volume with the uniform insonation method. The cursor was positioned in an area of the vessel with apertures to measure the spectral trace of flow spectral curve and vascular index, which were obtained automatically following software identification of the ultrasonic scanner for each waveform (Feliciano et al., 2012).

The power Doppler function was used to increase the sensitivity of the blood flow measurements and to transform the examination from angle-independent to insonation or incident angle (Drost, 2007). 


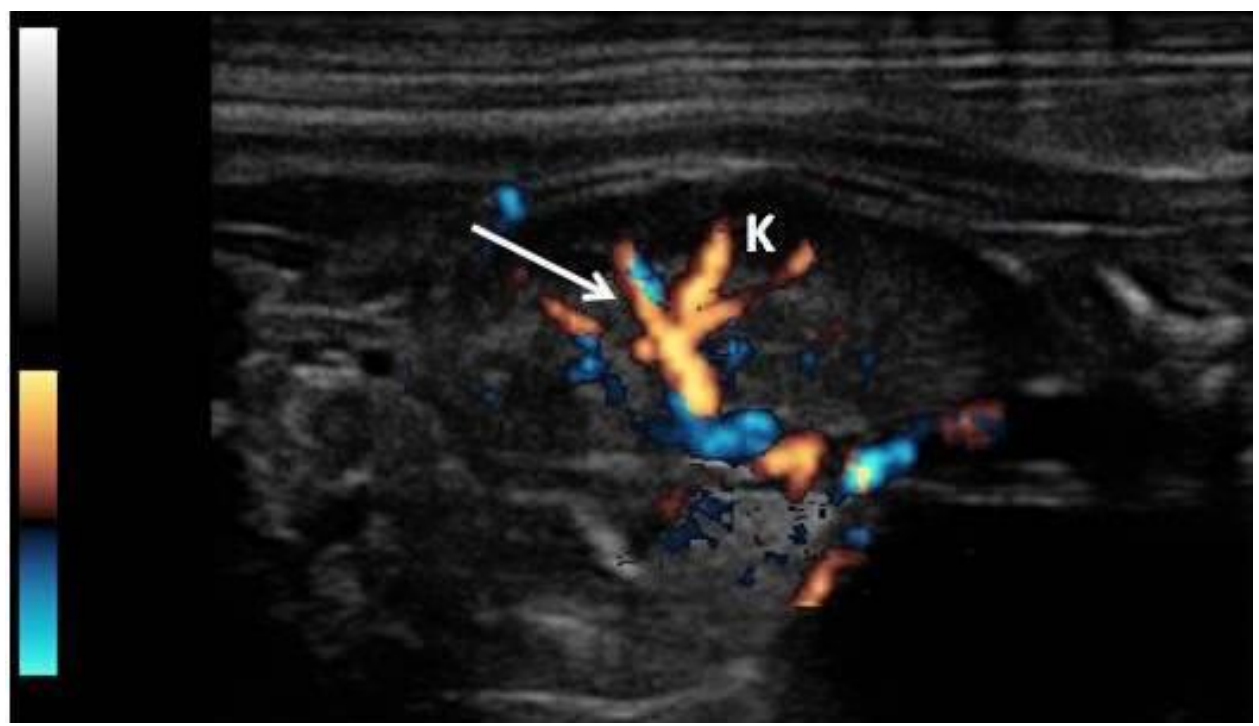

Figure 1. Sonographic imaging of the canine fetal kidney Triplex Doppler. (A) Note the presence of vascularization (arrow) in the fetal kidney (k).

Data were previously tested for normality of residuals and homogeneity of variances (F test). The PROC MEANS-SASTM and the GraphPad Prisma $4^{\mathrm{TM}}$ softwares were used. Significance level was $5 \%$ for all tests.

Raw and transformed averages were evaluated using analysis of variance and, additionally, the t-test for paired samples was applied and Tukey's multiple comparison test between the weeks was employed. Significance level was expressed as a $P$-value.

\section{RESULTS}

The mean pregnancy period was 58 days, with an average of 4 healthy pups per litter. The detection of the fetal kidneys of the majority of the conceptus occured from the $6^{\text {th }}$ week of pregnancy. In three cases it was possible to detect the fetal kidneys on the $5^{\text {th }}$ week of pregnancy.

The fetal kidneys assessed by conventional ultrasound were morfophogicaly normal, with regular surfaces, normal echotexture, lower echogenicity in comparison to the maternal kidneys, preserved cortical-medular ratio and positioned in situ during the gestational development stage.

The values of fetal kidney echobiometry obtained during the gestational development increased significantly from the 5th to the 8th week of pregnancy $(\mathrm{P}<0.001)$. The mean values of canine fetal renal echobiometry are displayed in Table 1.

The mean values of the vascular index of the renal arteries of canine fetuses are displayed on Table2.

Table 1. Mean values of canine fetal renal echobiometric parameters

\begin{tabular}{|c|c|c|c|c|c|}
\hline \multirow[b]{2}{*}{ Parameters } & \multicolumn{4}{|c|}{ Weeks of pregnancy } & \multirow[b]{2}{*}{$P(5 \%)$} \\
\hline & 5 th & 6th & 7 th & 8th & \\
\hline Length $(\mathrm{cm})$ & $0.56 \pm 0.12$ & $0.98 \pm 0.23$ & $1.5 \pm 0.28$ & $1.82 \pm 0.25$ & $<0.0001^{*}$ \\
\hline Wide $(\mathrm{cm})$ & $0.35 \pm 0.07$ & $0.59 \pm 0.15$ & $0.87 \pm 0.16$ & $1.02 \pm 0.12$ & $<0.0001^{*}$ \\
\hline Area $\left(\mathrm{cm}^{2}\right)$ & $0.18 \pm 0.07$ & $0.47 \pm 0,22$ & $1.04 \pm 0,36$ & $1.47 \pm 0.42$ & $<0.0001^{*}$ \\
\hline Volume $\left(\mathrm{cm}^{3}\right)$ & $0.05 \pm 0.03$ & $0.21 \pm 0.14$ & $0.62 \pm 0.33$ & $0.99 \pm 0.41$ & $<0.0001^{*}$ \\
\hline
\end{tabular}

t-test for paired samples at 5\% significance level. * Significant if $P<0.05$

The view of the fetal renal vascularization using Doppler Triplex occured from the $6^{\text {th }}$ week of pregnancy. PSV and EDV increased along the weeks of pregnancy $(P<0.05)$. There were no alterations on fetal renal PI and RI during pregnancy $(P>0.05)$. 
Table 2. Mean values of canine fetal renal artery index

\begin{tabular}{ccccc} 
& \multicolumn{3}{c}{ Weeks of pregnancy } & \\
\cline { 2 - 4 } Index & 6th & 7 th & 8th & $P \%)$ \\
\hline PSV $(\mathrm{cm} / \mathrm{s})$ & $9.28 \pm 1.55$ & $11.61 \pm 2.3$ & $11.81 \pm 1.4$ & $<0.0001^{*}$ \\
EDV $(\mathrm{cm} / \mathrm{s})$ & $2.53 \pm 0.66$ & $2.84 \pm 0.80$ & $3.26 \pm 0.66$ & $0.0095^{*}$ \\
PI & $1.86 \pm 0.29$ & $2.01 \pm 0.29$ & $1.89 \pm 0.23$ & 0,1862 \\
RI & $0.80 \pm 0.06$ & $0.83 \pm 0.05$ & $0.82 \pm 0.04$ & 0,2131 \\
\hline
\end{tabular}

t-test for paired samples, 5\% significance level. Peak sistolic velocity (PSV), end diastolic velocity (EDV), vascular resistance (RI) and pulsatility (PI) index. * Significant if $P<0.05$

\section{DISCUSSION}

Studies described by Rivers et al. (1997) and Feliciano et al. (2008) demonstrated the importance of B mode and Doppler ultrasounds for the diagnosis of kidney disease in dogs. Due to the importance of these imaging techniques, we believe that the present study is of great value for the prenatal diagnosis of congenital and hereditary kidney disease in dogs, such as polycystic kidney disease, renal hypoplasia/agenesis and ectopic kidneys, nephromegalia and other changes mentioned by Noronha et al. (2003) in which there are changes in normal sonographic findings of kidneys.

The ultrasound techniques used in the current study were easily conducted, which may be of great value regarding the early-stage diagnosis of hereditary or congenital renal abnormalities in dogs, as sereval renal diseases are triggered following the emergence of shape, size, echogenicity, echotexture and cortical-medular ratio related disorders (Gray 1996; Feliciano et al., 2008; Santana et al., 2009).

In a study involving ultrasonography in adult dogs, the renal length and width ranged from 3 to $9 \mathrm{~cm}$ and from 2 to $5 \mathrm{~cm}$, respectively (Feeney et $a l ., 2007)$. In another trial, the average renal volume of adult dogs ranged from (Sampaio et al., 2002) $2.14 \pm 0.446 \mathrm{~cm}^{3} / \mathrm{kg}$, which was within the normal paterns. The determination of linear parameters (length, width and thickness) and renal volume in canine fetuses is important for the diagnosis of renal congenital and hereditary disorders.

There are no reports regarding the assessment of the fetal renal arteries using the Doppler Triplex technique in the veterinary setting. Therefore, the current study complements the results of other trials involving the pulse Doppler for the evaluation of the canine renal arteries (Blanco et al., 2011), which was also considered suitable for early-stage detection of gestational abnormalities in bitches.

Regarding the evaluation of the renal artery index in adult dogs, other studies reported PSV ranging from 70 to $90 \mathrm{~cm} / \mathrm{s}$ and EDV ranging from 23 to $33 \mathrm{~cm} / \mathrm{s}$ using the Doppler Duplex (Melo et al., 2006), which were higher than the measurements obtained in the current trial.

Regarding the PI and RI of fetal renal arteries, the values obtained in the current study were higher than those found in other researches involving adult dogs (Novellas et al., 2007; Santana et al., 2009). Santana et al. (2009) obtained 0.71 for RI and 1.56 for PI, and found 0.72 for RI and 1.52 for PI (Novellas et al., 2007).

According to another research that evaluated human neonates in the first weeks of age (Cleary et al., 1996), the vascular index increased due to increased blood flow on the large abdominal vessels and greater renal vascular resistance. Such results support the findings of the current study involving canine fetuses. Moreover, another trial reported increased PSV and EDV during the fetal development phase and constant values for PI and RI in bitches with normal pregnancies (Blanco et al., 2011).

\section{ACKNOWLEDGEMENTS}

The authors would like to thank FAPESP for the financial support in the current research and for post-doctor scholarship support (processes 2010/16913-7 and 2011/06011-9). 


\section{CONCLUSIONS}

In conclusion, the B mode ultrasound and the Doppler Triplex provided accurate evaluation of the canine fetal renal morfological parameters and unpublished fetal renal echobiometry and renal artery vascular index, which may play a coadjuvante role on the early-stage diagnosis of congenital renal disorders in canine fetuses.

\section{REFERENCES}

BLANCO; P.G.; RODRIGUEZ, R.; RUBE, A. et al. Doppler ultrasonographic assessment of maternal and fetal blood flow in abnormal canine pregnancy. Anim. Reprod. Sci., v.126, p.130-135, 2011.

CLEARY, G.M.; HIGGINS, S.T.; MERTON, D.A. et al. Developmental changes in renal artery blood flow velocity during the first three weeks of life in preterm neonates. JPED, v.129, p.251-257, 1996.

DROST, W.T. Basic ultrasound physics. In: TRHALL, D.E. (Ed). Veterinary Diagnostic Radiology. 5th ed. St Louis: Eds. Saunders Elsevier, 2007. p.38-49.

FELICIANO, M.A.R.; MUZZI, L.A.L.; LEITE, C.A.L. et al. Two-dimensional conventional, high resolution two-dimensional and threedimensional ultrasonography in the evaluation of pregnant bitch. Braz. J. Vet. Res. Anim. Sci., v.59, p.1333-1337, 2007.

FELICIANO, M.A.R.; LEITE, C.A.L.; SILVEIRA, T. et al. Cystic medullary renal disease in a Yorkshire Terrier bitch: a case report. Braz. J. Vet. Res. Anim. Sci., v.60, p.832-836, 2008.

FELICIANO, M.A.R.; VICENTE, W.R.R.; SILVA, M.A.M. Conventional and Doppler ultrasound for the differentiation of benign and malignant canine mammary tumours. JSAP, v.53, p.332-337, 2012.
FEENEY, D.A.; JOHNSTON, G.R. The kidneys and ureters. In: THRALL D.E. (Ed). Veterinary Diagnostic Radiology. 5th ed. St Louis: Eds. Saunders Elsevier, 2007. p. 693-697.

GRAY, W. Renal and hepatic ultrasonographyin the neonatal dog. Vet. Radiol. Ultrasound, v.37, p.374-82, 1996.

MELO, M.B.; VEADO, J.C.C.; SILVA, E.F. et al. Renal arteries Dopplerfluxometry: normal systolic and diastolic flow velocities and resistive index values in the main renal arteries. Braz. J. Vet. Res. Anim. Sci., v.58, p.691-693, 2006.

NORONHA, L.; REICHERT, A.; MARTINS, V.D.M. et al. Study of urinary tract congenital malformations: analysis of 6,245 pediatric autopsies. J. Bras. Patol. Med. Lab., v.39, p.237243, 2003.

NOVELLAS, R.; ESPADA, Y.; RUIZ DE GOPEGUI, R. Doppler ultrasonographic estimation of renal and ocular resistive and pulsatility indices in normal dogs and cats. Vet. Radiol. Ultrasound, v.48, p.69-73, 2007.

RIVERS, B.J.; WALTER, P.A.; POLZIN, D.J. et al. Duplex doppler estimation of intrarenal pourcelot resistive index in dogs and cats with renal disease. J. Vet. Int. Med., v.11, p.250-260, 1997.

SAMPAIO, K.M.O.R.; ARAÚJO, R.B. Ultrasonographic measurement of linear characteristics and renal volumetry in dogs. Braz. J. Vet. Res. Anim. Sci., v.54, p.248-254, 2002.

SANTANA, E.J.M.; BESERRA, P.S.; BRITO, A.B. et al. Renal artery triplex doppler and the relationship between kidney ecobiometry with atlanto-coccyges distance (acd) and height (h) in canis familiaris. Braz. J. Vet. Res., v.29, p.809815, 2009. 